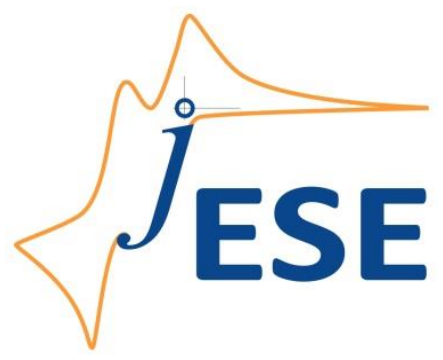

Open Access: ISSN 1847-9286 www.jESE-online.org

Original scientific paper

\title{
Analytical method for heavy metal determination in algae and turtle eggs from Guanahacabibes Protected Sea Park
}

\author{
Abel I. Balbín Tamayo ${ }^{\bowtie}$, Ana M. Esteva Guas, Juan J. Piña Leyte-Vidal and \\ Marcelo Maccini* \\ Department of Analytical Chemistry, Faculty of Chemistry, University of Havana, Havana, 10400, \\ Cuba \\ *Department of Food Science, University of Teramo, 64023, Teramo, Italy \\ Corresponding author: E-mail: ibrahim@fq.uh.cu; Tel.: +538738222
}

Received: February 4, 2014; Revised: April 4, 2014; Published: December 6, 2014

\begin{abstract}
A standard digestion method coupled to electrochemical detection for the monitoring of heavy metals in biological samples has been used for the simultaneous analysis of the target analytes. Square wave anodic stripping voltammetry (SWASV) coupled to disposable screen-printed electrodes (SPES) was employed as a fast and sensitive electroanalytical method for the detection of heavy metals. The aim of our study was to determine $\mathrm{Cd}, \mathrm{Pb}$ and $\mathrm{Cu}$ by SWASV in brown algae (Sargasum natan) and green turtle eggs (Chelonia mydas) using screen-printed electrodes. The method proved useful for the simultaneous analysis of these metals by comparison between two different procedures for preparing the samples. Two different approaches in digestion protocols were assessed. The study was focused on Guanahacabibes brown algae and green turtle eggs because the metal concentrations recorded in this area may be used for intraspecific comparison within the Guanahacabibes Protected Sea Park area, a body of water for which information is still very scarce. The best results were obtained by digesting biological samples with the EPA $3050 B$ method. This treatment allowed the fast and quantitative extraction from brown algae and green turtle eggs of the target analytes, with high sensitivity and avoiding organic residues, eventually affecting electrochemical measurements.
\end{abstract}

\section{Keywords}

Cadmium; copper; lead; Sargasum Natan; Chelonia Mydas eggs; square-wave anodic stripping

\section{Introduction}

Marine contaminations by anthropogenic chemicals pose one of the worst problems to coastal and estuarine ecosystems around the word. Certain heavy metals have gained great significance in chemical and toxicological studies of the environment. Among those heavy metals are $\mathrm{Cd}$ and $\mathrm{Pb}$, 
which are generally toxic even at very low levels, and potentially toxic metals, e.g. Cu which also has indispensable essential properties with different threshold levels in different types of plants and organisms, including man. Therefore, the evaluation of heavy metal concentrations in marine organisms constitutes an important area of research [1-4].

The use of marine organisms (algae, turtles eggs, fish, etc.) as bioindicators to trace metal pollution is very common these days [5-7].

Macroalgae are able to accumulate trace metals, reaching concentrations that are thousands of times higher than the corresponding concentrations in sea water. Algae accumulate only free metal ions, the concentrations of which depend on the nature of suspended particulate matter [8], which, in turn, is formed by both organic and inorganic complexes. Moreover, algae satisfy all of the basic requirements of bioindicators: they are sedentary, their dimensions are suitable, they are easy to identify and collect, they are widely distributed, and they accumulate metals to a satisfactory degree [9].

On the other hand, many investigations have reported the accumulation of heavy metals in marine sea turtle having a long lifespan and occupying high trophic levels in the marine food chains, and showed the utility of this specie as a biological indicator of heavy metal pollution. The intentional killing of any living sea turtle is prohibited, except for research purposes, for which only very limited samples are available. Hence, it is possible to estimate the concentration of heavy metals in the tissue of nesting female sea turtles by using their eggs [10-15]. For that reason, the eggs are a useful non-lethal indicator for monitoring heavy metals in the body of sea turtles.

A wet-digestion procedure can be applied to all types of biological materials. In this procedure, small amounts of nitric and perchloric acids are added to the sample material. The overall reliability of the digestion method will follow the adequate mineralisation of samples, i.e. the levels of the heavy metals. If any metals were linked in their insoluble form, they are not of relevance for pollution control [16].

The digestion method involves the liberation of the analyte (metal) of interest from an interfering matrix using a reagent (mineral/oxidising acids or fusion flux) and/or heat. The utilisation of reagents (acids) and external heat sources can then cause problems. In elemental analysis, these problems are particularly focused on the risk of contamination and loss of analytes [17-19].

Considering the low content of heavy metals in environmental samples, sensitive analytical methods are required. The heavy metal determination in organic samples can usually be carried out by atomic spectrometry: inductively-coupled plasma optical emission (ICP-OES) or electrothermal and flame atomic absorption spectrometry (ETAAS and FAAS), although the detection limits are not sufficient when the concentrations are too low. However, many preconcentration techniques have been employed for analysing complex matrices and samples with low levels of metals. Hence, square-wave anodic stripping voltammetry (SWASV) includes a preconcentration step in situ; for this reason, this is an electroanalytical technique used for the analysis of traces metals in solution [20-27]. Such a combination of an effective accumulation step with an advanced measurement procedure results in a very low detection limit, and makes stripping analysis one of the most important techniques in trace analysis.

The coupling of disposable screen-printed electrodes with stripping techniques is a revolution in comparison with conventional stripping analysis: the design and operation are greatly simplified, in accordance with the requirements of a decentralised assay. The greater proportion of articles 
have utilised the technique of stripping voltammetry, gaining detection limits in the low $\mathrm{ng} / \mathrm{mL}$ (ppb) region [28].

Screen-printed electrodes are planar devices realised by printing layers of different electroconductive and insulating inks with controlled thickness and shapes on a plastic substrate. In this work, the carbon surface of the screen-printed working electrode was employed as a substrate for a thin mercury film (TMF) [29].

The aim of our study was to apply a digestion method (EPA 3050B) to determine $\mathrm{Cd}, \mathrm{Pb}$ and $\mathrm{Cu}$ by square-wave anodic stripping voltammetry in brown algae (Sargasum natan) and green turtle (Chelonia mydas) eggs, using a screen-printed electrode, and it demonstrated the usefulness of this method for the simultaneous analysis of $\mathrm{Cd}, \mathrm{Pb}$ and $\mathrm{Cu}$ by comparison between two different procedures for preparing the samples.

\section{Experimental}

\section{Collecting and treatment of samples}

The study area was located in Antonio beach Guanahacabibes Protected Sea Park. This site is situated in an area characterised by low anthropogenic activity [30].

The sample of brown algae (Sargasum natan) was handpicked in the subtidal zone at a depth of about 2-3 m. Care was taken to choose the sample to ensure that all were at a similar stage of development. The samples were washed in seawater at the sampling site and transferred to the laboratory in pre-cleaned polyethylene bags under refrigerated conditions. Upon arrival at the laboratory, they were thoroughly cleaned and any sediment was carefully removed with nylon brushes under tap water for a few seconds. Algal material was rapidly rinsed in deionised water (Milli-Q, Millipore Corp) to minimise any possible metal loss during the procedure and was then pulverised. Finally, the samples were frozen and stored $\left(4{ }^{\circ} \mathrm{C}\right)$ until analysis.

The green turtle (Chelonia mydas) egg samples were collected in the nesting area of this species. All samples were stored at $4{ }^{\circ} \mathrm{C}$ until chemical analysis, and then the eggshell, the albumen and the yolk were subsequently separated. The separation was carried out quickly to prevent thawing.

Samples were digested by two separate digestion procedures in order to select the simplest, which in turn would provide suitable analytical results:

a) General acid digestion: A $1 \mathrm{~g}$ dried sample was placed in a Teflon beaker; the acid digestion reagent (concentrated $\mathrm{HNO}_{3}$ ) was added and the mixture was allowed to stand overnight. The sample was heated until the production of red $\mathrm{NO}_{2}$ fumes had ceased. This mixture was digested via the addition of $\mathrm{HClO}_{4}$ and was heated until it had evaporated to a small volume. The samples were brought to an appropriate volume with a dilute acid solution $\left(0.01 \mathrm{~mol} \mathrm{~L}^{-1}\right.$ $\mathrm{HCl})$.

b) The method EPA 3050B $[17,18,31]$ was used to produce a transparent solution. This is a very strong acid digestion that will dissolve almost all elements that could become "environmentally available". For the digestion of samples, a representative $1 \mathrm{~g}$ (dry weight) sample was digested with the repeated addition of nitric acid $\left(\mathrm{HNO}_{3}\right)$ and hydrogen peroxide $\left(\mathrm{H}_{2} \mathrm{O}_{2}\right)$. The resultant solutions were diluted to a known volume with $0.01 \mathrm{~mol} \mathrm{~L}^{-1} \mathrm{HCl}$.

For each analytical batch of samples processed, blanks were carried throughout the entire sample preparation and analytical process. These blanks will be useful for determining whether samples are contaminated, and are necessary to provide a realistic estimate of interferences that could be encountered in the analysis of test samples. 


\section{Heavy metal determination}

All experiments were carried out using a PalmSens portable electrochemical analyser (Palmsens BV, Houten, The Netherlands). The conditions for square wave voltammetry striping onto a screenprinted electrode of carbon modified by plated $\mathrm{Hg}$ films were:

$\mathrm{Cd}(\mathrm{II}), \mathrm{Pb}(\mathrm{II})$ and $\mathrm{Cu}(\mathrm{II})$ analysis: conditioning potential $\left(E_{\text {cond }}\right)-0.3 \mathrm{~V}$ for $60 \mathrm{~s}$, deposition potential $\left(E_{\text {dep }}\right)-1.0 \mathrm{~V}$ for $300 \mathrm{~s}$, equilibration time $\left(t_{\text {eq }}\right) 30 \mathrm{~s}$, SW amplitude $\left(E_{\text {amp }}\right) 28 \mathrm{mV}$, step potential $\left(E_{\text {step }}\right) 3 \mathrm{mV}$, frequency $(f) 15 \mathrm{~Hz}$.

Electrodes were serigraphically screen-printed with a shape similar to that reported by Palchetti [29]. They consisted of a round-shaped working electrode (diameter $3 \mathrm{~mm}$ ), a graphite counter electrode and a silver pseudo-reference electrode. In addition, the silver electrical contacts were covered by a graphite layer in order to prevent oxidation phenomena during storage.

Graphite-based Hg-modified screen-printed electrodes were used as the working electrode. These are based on the use of a special coating cellulose-derivative film deposited onto the graphite working electrodes containing a $\mathrm{Hg}$ (II) salt, as reported by Meucci [32]. $\mathrm{Hg}$ (II) is reduced from the salt to the metallic form and the modified sensor can be then used for heavy metal accumulation and stripping. The use of this strategy allows the use of large amounts of $\mathrm{Hg}$ solutions to be avoided, whilst retaining the high sensitivity which characterises mercury-coated electrodes [32].

Each sensor was pre-treated in $0.1 \mathrm{~mol} \mathrm{~L}^{-1} \mathrm{HCl}$ before being used for the first time, by applying ten cycles of square wave voltammetry (SWV) using the following conditions: potential initial $1 \mathrm{~V}$, potential final $0 \mathrm{~V}$, scan rate $50 \mathrm{mV} \mathrm{s}^{-1}, \mathrm{SW}$ amplitude $\left(E_{\text {amp }}\right) 28 \mathrm{mV}$, step potential $\left(E_{\text {step }}\right) 3 \mathrm{mV}$, frequency $(f) 15 \mathrm{~Hz}$. This step is necessary to obtain a stable baseline.

Then, $0.1 \mathrm{~mol} \mathrm{~L}^{-1} \mathrm{HCl}$ was used as the supporting electrolyte. All measurements were performed without removing oxygen from the solution. The measurements were performed by immersing the sensor in $5.0 \mathrm{ml}$ of solution, with magnetic stirring during the conditioning and accumulation steps, whereas the square wave scan was performed without stirring.

Suprapure grade hydrochloric acid was purchased from Merck. The water used for the preparation of solutions was from a Milli-Q System (Millipore). The working standard solution of $\mathrm{Cd}, \mathrm{Pb}$ and $\mathrm{Cu}$ was prepared by diluting standard $1 \mathrm{~g} \mathrm{~L}^{-1}$ metal solutions with $0.01 \mathrm{~mol} \mathrm{~L}^{-1} \mathrm{HCl}$.

\section{Statistical analysis}

For the statistical treatment, the experimental results followed the recommendations proposed by Miller [33]. Determinations of means, standard deviations, coefficients of variation and percentage recovered were performed using statistical software.

LOD: The limit of detection, expressed as the concentration $c_{L}$, or the quantity $q_{L}$, is derived from the smallest measure $x_{\mathrm{L}}$, that can be detected with reasonable certainty for a given analytical procedure. The value of $x_{L}$ is given by equation (1):

$$
x_{\mathrm{L}}=x_{\mathrm{bl}}+k_{\mathrm{sbl}}
$$

LOQ: The lowest concentration of an analyte that can be determined with acceptable precision (repeatability) and accuracy under the stated conditions of the test.

The ability to quantify is generally expressed in terms of the signal or analyte (true) value that will produce estimates with a specified relative standard deviation (RSD), which is commonly $10 \%$. 


\section{Results and Discussion}

When measurements are made at low analyte levels, e.g. in trace analysis, it is important to determine the lowest concentration of the analyte or property value that can be confidently detected by the method, and the lowest concentration of analyte that can be determined with an acceptable level of repeatability, precision and trueness. The importance in determining this, and the problems associated with it, arises from the fact that the probability of detection does not suddenly change from zero to unity as some threshold is crossed. The detection and quantification limits for the general acid digestion and EPA 3050B by square wave voltammetry striping methods are shown in Table 1.

With these procedures for preparing the samples, tiny, clear, well-separated signals corresponding to the different metals were recorded by SWASV; no matrix effect and reproducible peaks and linear standard addition plots were observed in digested reagent blanks.

The mean calculated detection limits method (based on three times the standard deviation of the blank signal) and quantification limits (based on ten times the standard deviation of the blank signal) for $\mathrm{Cd}, \mathrm{Pb}$ and $\mathrm{Cu}$ showed a marked improvement over those reported by Wang, Locatelli and Palchetti $[25,34,35]$.

Taking into account the low detection limits, quantification limits and coefficient of variation (CV) in Table 1, the general acid digestion and EPA 3050B using square wave voltammetry anodic striping methods give good estimations for the metals analysed.

Table 1. Detection limits, quantification limits and coefficient of variation for $\mathrm{Cd}, \mathrm{Pb}$ and $\mathrm{Cu}$ for general acid digestion and method EPA $3050 B$ by square wave voltammetry anodic striping.

\begin{tabular}{ccccccc}
\hline \multirow{2}{*}{ Metal } & \multicolumn{3}{c}{ General acid digestion } & \multicolumn{4}{c}{ Method EPA 3050B } \\
\cline { 2 - 7 } & $\mathrm{LOD}, 10^{-4} \mu \mathrm{g} / \mathrm{g}_{\text {dry }}$ & $L O Q, 10^{-4} \mu \mathrm{g} / \mathrm{g}_{\text {dry }}$ & $\mathrm{CV}, \%$ & $\left.\mathrm{LOD}, 10^{-4} \mu \mathrm{g} / \mathrm{g}_{\text {dry }}\right)$ & $\mathrm{LOQ}, 10^{-4} \mu \mathrm{g} / \mathrm{g}_{\text {dry }}$ & $\mathrm{CV}, \%$ \\
\hline $\mathrm{Cd}$ & 12.5 & 15 & 1.6 & 13 & 19 & 1.5 \\
\hline $\mathrm{Pb}$ & 310 & 350 & 3.2 & 150 & 200 & 6.6 \\
\hline $\mathrm{Cu}$ & 210 & 240 & 4.7 & 118 & 130 & 3.4 \\
\hline
\end{tabular}

Determination of heavy metals in brown algae (Sargasum natan) and green turtle (Chelonia mydas) eggs

All metal contents reported in this work refer to the initial dry mass. Mean metal concentrations are reported as values with standard deviations. $\mathrm{Cd}, \mathrm{Pb}$ and $\mathrm{Cu}$ concentrations in brown algae and green turtle eggs are shown in Table 2 and 3 for the general acid digestion and EPA 3050B methods, respectively. The standard deviations of pooled samples refer to the variability within different replicates.

For these procedures for preparing the samples, SWASV recorded tiny, clear, well-separated signals corresponding to the different metals (Figs. 1-4); no matrix effect, reproducible peaks and linear standard addition plots were observed in the digested biological matrix.

Different concentrations of $\mathrm{Cd}, \mathrm{Pb}$ and $\mathrm{Cu}$ were used to perform linear regression analysis for the utilised screen-printed electrodes. The linear regression analysis, generated by plotting the height of the peaks obtained for each concentration, gave the following equations:

- General acid digestion of brown algae

for $\mathrm{Cd}: i_{\mathrm{p}}=0.24+10.7 c_{\mathrm{Cd}}, \quad$ for $\mathrm{Pb}: i_{\mathrm{p}}=6+383 c_{\mathrm{Pb}} \quad$ for $\mathrm{Cu}: i_{\mathrm{p}}=10.8+356 c_{\mathrm{Cu}}$

- General acid digestion of green turtle eggs 
for Cd: $i_{\mathrm{p}}=0.198+9 c_{\mathrm{Cd}}$

for $\mathrm{Pb}: i_{\mathrm{p}}=3.22+42 c_{\mathrm{Pb}}$

for $\mathrm{Cu}: i_{\mathrm{p}}=3.5+44 c_{\mathrm{Cu}}$

- EPA 3050B of brown algae

for $\mathrm{Cd}: i_{\mathrm{p}}=0.43+16 c_{\mathrm{Cd}}, \quad$ for $\mathrm{Pb}: i_{\mathrm{p}}=3.38+227 c_{\mathrm{Pb}} \quad$ for $\mathrm{Cu}: i_{\mathrm{p}}=3.95+59 c_{\mathrm{Cu}}$

- EPA 3050B of green turtle eggs

for $\mathrm{Cd}_{\mathrm{p}} i_{\mathrm{p}}=0.27+6.6 c_{\mathrm{Cd}}, \quad$ for $\mathrm{Pb}: i_{\mathrm{p}}=7.64+84 c_{\mathrm{Pb}} \quad$ for $\mathrm{Cu}: i_{\mathrm{p}}=7.9+88 c_{\mathrm{Cu}}$

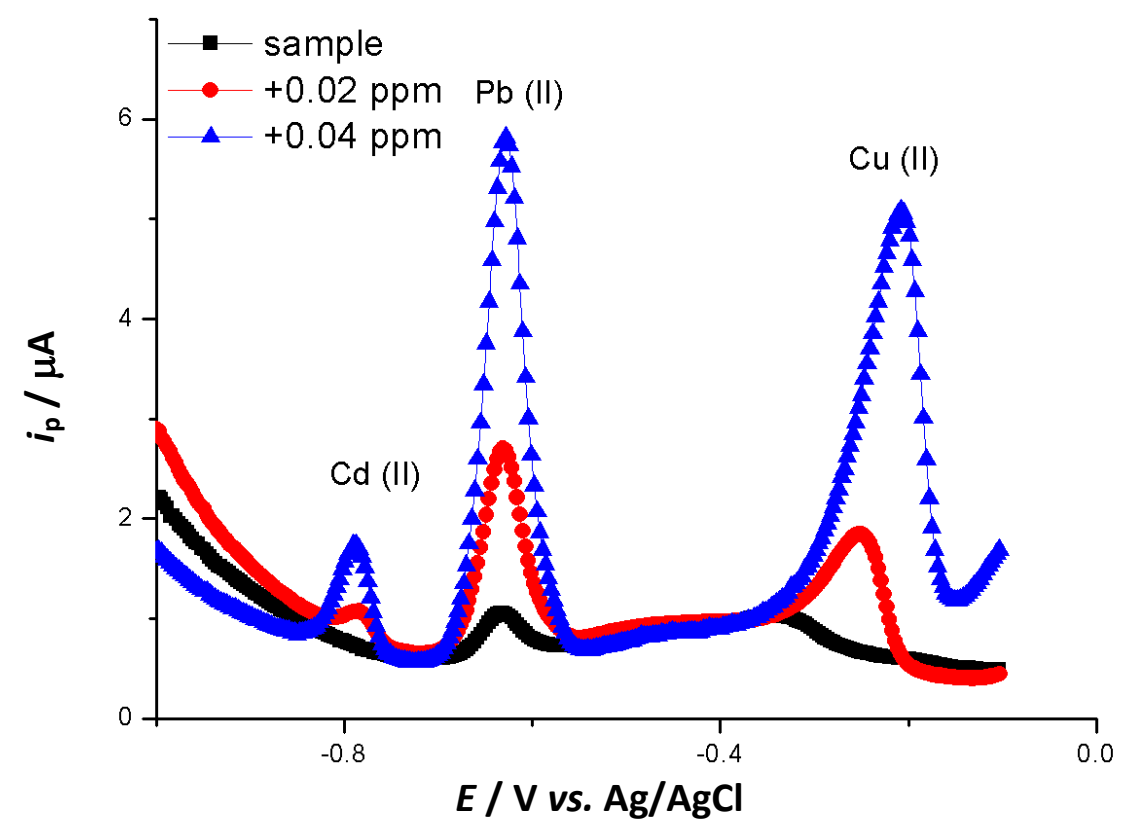

Figure 1. Signals corresponding to standard addition the different metals concentration to brown algae samples digest by method General acid digestion. +0.02 ppm and +0.04 ppm of multistandard of $\mathrm{Cd}(\mathrm{II}), \mathrm{Pb}(\mathrm{II}), \mathrm{Cu}$ (II)

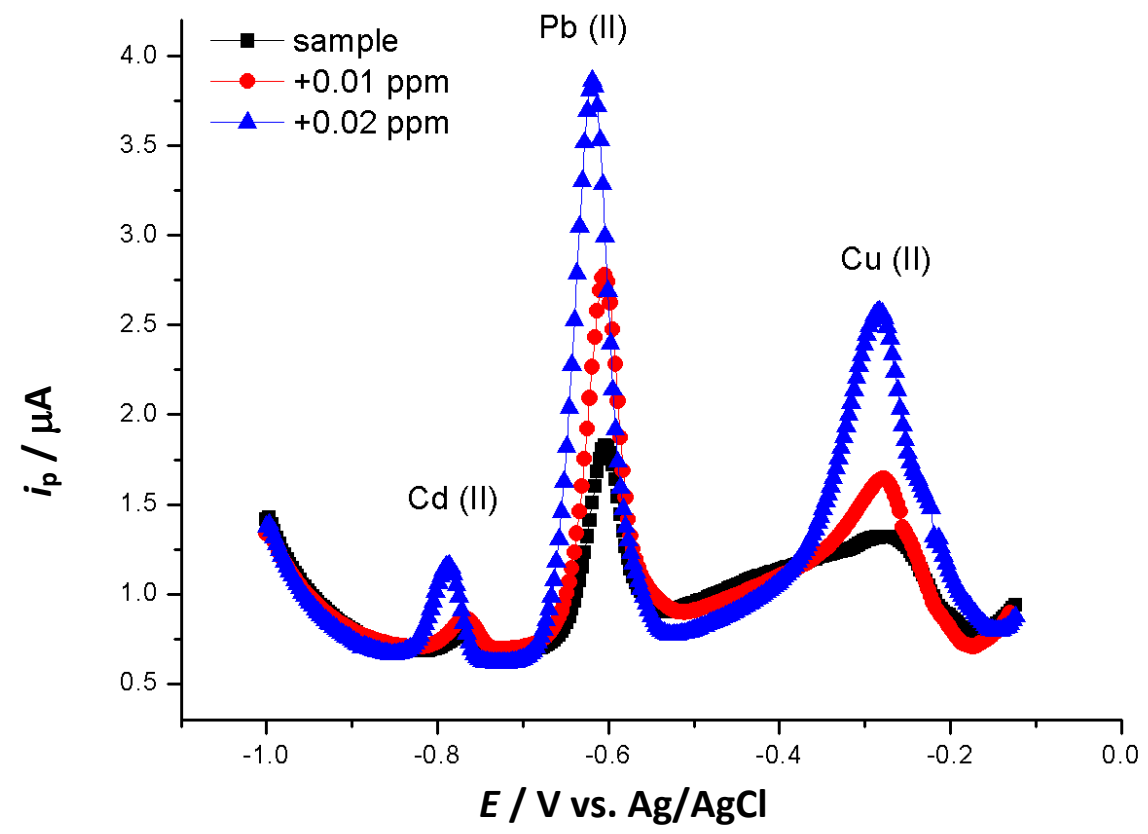

Figure 2. Signals corresponding to standard addition the different metals concentration to green turtles eggs samples digest by method General acid digestion $+0.01 \mathrm{pm}$ and $+0.02 \mathrm{ppm}$ of multistandard of $C d(I I), P b(I I), C U$ (II). 


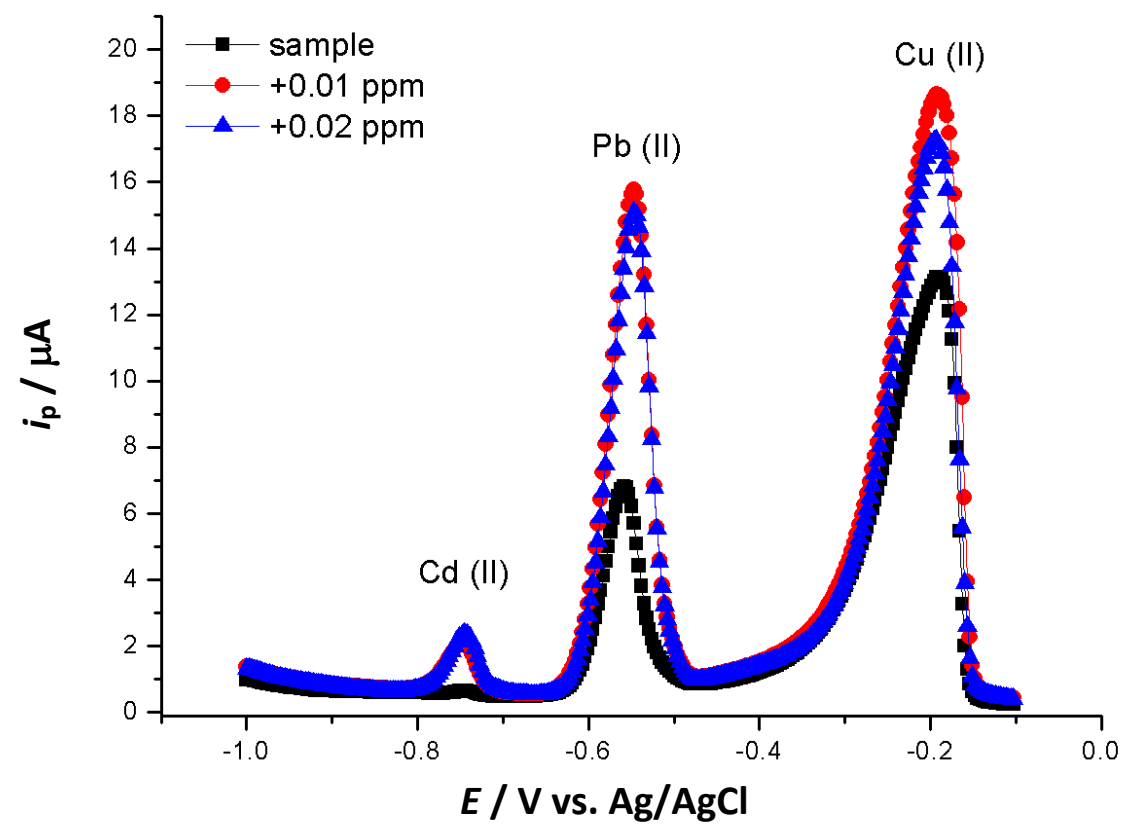

Figure 3. Signals corresponding to standard addition the different metals concentration to brown algae samples digest by method EPA 3050B. +0.01 ppm and +0.02 ppm of multistandard of $C d(I I), P b(I I), C u(I I)$

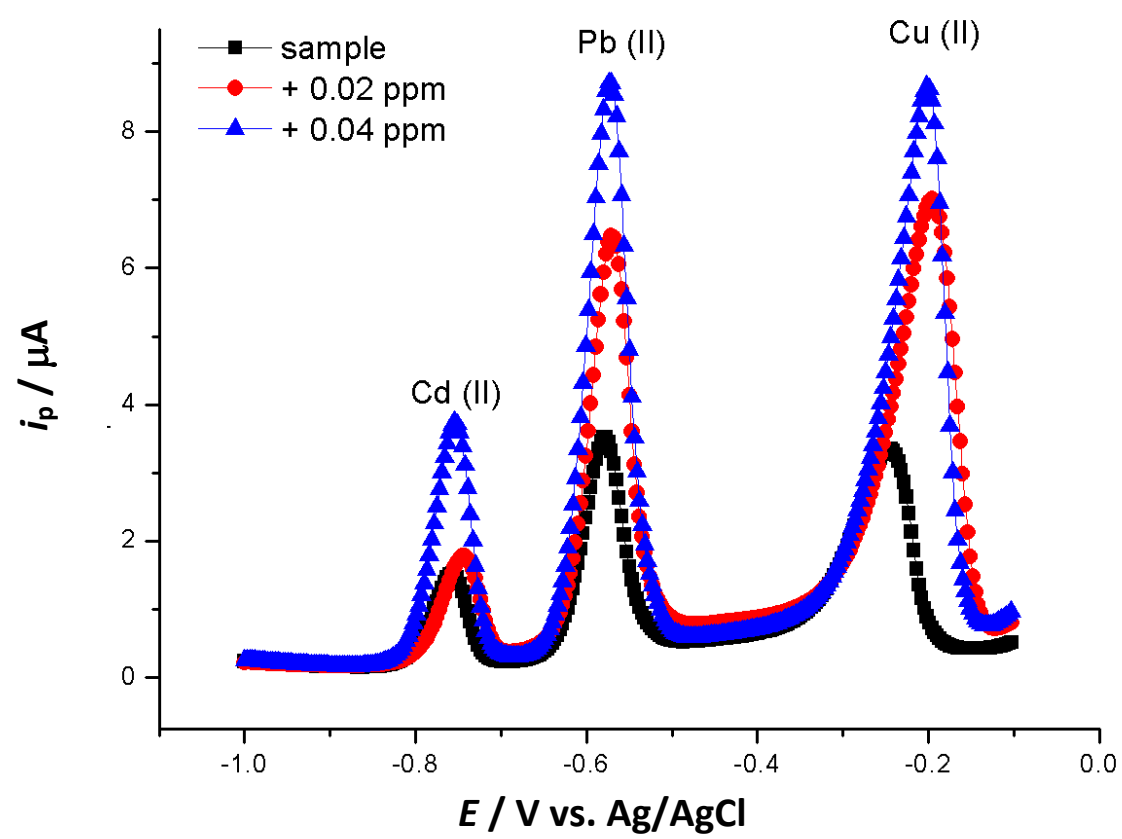

Figure 4. Signals corresponding to standard addition the different metals concentration to green turtles eggs samples digest by method EPA $3050 B+0.02 \mathrm{ppm}$ and $+0.04 \mathrm{ppm}$ of multistandard of $\mathrm{Cd}(\mathrm{II}), \mathrm{Pb}(\mathrm{II}), \mathrm{Cu}$ (II)

In all cases, linearity ranging from $10 \mathrm{ppm}$ to $30 \mathrm{ppm}$ was obtained with a correlation $\geq 0.98$ for all of the metals analysed.

The values determined in the brown alga and turtle eggs generally had low values of standard deviation and a coefficient of variation of $5 \%$ for both moist digestion techniques used to digest the brown seaweed and green turtle eggs; this is indicative of analytical quality results. 
The samples were analysed by the method under validation both in its original state and after the addition (spiking) of a known mass of the analyte to the test sample. In the absence of reference materials, bias was investigated by spiking and recovery $[22,35]$.

Spiking/recovery studies are very strongly subjective; the recoveries that are significantly different from unity indicate that bias is affecting the method. Better spiking/recovery data were obtained by the EPA 3050B method, even though the poor recovery by general acid digestion was certainly an indication of a lack of trueness.

The variation between the spiking/recovery data using different digestion methodologies may not only be due to volatility during digestion but could also be linked to the way in which these elements are attached to the biological matrix.

On the other hand, the bioaccumulation of these metals in brown algae is influenced by numerous factors: $\mathrm{pH}$, ligand concentration and type, and various sediment components [36-38]. Trace metal concentrations reported in this study were of the same order of magnitude as those measured by other authors in uncontaminated sites [36,39]. These analysed metals in brown algae showed low anthropogenic activity.

Table 2. Concentration of Heavy metals in brown algae (Sargasum natan) and in green turtle eggs (Chelonia mydas) by general acid digestion

\begin{tabular}{|c|c|c|c|c|c|c|}
\hline \multirow[b]{2}{*}{ Metal } & \multicolumn{3}{|c|}{ Brown algae (Sargasum natan) } & \multicolumn{3}{|c|}{ Green turtle eggs (Chelonia mydas) } \\
\hline & $\begin{array}{c}\text { Means } \pm S D \\
\mu \mathrm{g} / \mathrm{g}_{\mathrm{dry}}\end{array}$ & $C V, \%$ & $\begin{array}{c}\text { Recuperation surrogate } \\
\text { recovery, \%* }\end{array}$ & $\begin{array}{c}\text { Means } \pm S D \\
\mu g / g_{d r y}\end{array}$ & $\mathrm{CV}, \%$ & $\begin{array}{c}\text { Recuperation surrogate } \\
\text { recovery, \%* }\end{array}$ \\
\hline $\mathrm{Cd}$ & $1.16 \pm 0.06$ & 5.0 & 89 & $2.2 \pm 0.1$ & 4.5 & 89 \\
\hline $\mathrm{Pb}$ & $0.79 \pm 0.01$ & 5.6 & 92 & $7.6 \pm 0.2$ & 2.6 & 90 \\
\hline $\mathrm{Cu}$ & $1.52 \pm 0.01$ & 1.0 & 78 & $7.7 \pm 0.2$ & 2.6 & 100 \\
\hline
\end{tabular}

Table 3. Concentration of Heavy metals in brown algae (Sargasum natan) and in green turtle eggs (Chelonia mydas) by EPA $3050 \mathrm{~b}$

\begin{tabular}{ccccccc}
\hline \multirow{2}{*}{ Metal } & \multicolumn{3}{c}{ Brown algae (Sargasum natan) } & \multicolumn{3}{c}{ Green turtle eggs (Chelonia mydas) } \\
\cline { 2 - 7 } & $\begin{array}{c}\text { Means } \pm \mathrm{SD}, \\
\mu \mathrm{g} / \mathrm{g}_{\mathrm{dry}}\end{array}$ & $\mathrm{CV}, \%$ & $\begin{array}{c}\text { Recuperation surrogate } \\
\text { recovery, \%* }\end{array}$ & $\begin{array}{c}\text { Means } \pm \mathrm{SD}, \\
\mu \mathrm{g} / \mathrm{g}_{\mathrm{dry}}\end{array}$ & $\mathrm{CV}, \%$ & $\begin{array}{c}\text { Recuperation surrogate } \\
\text { recovery, \%* }\end{array}$ \\
\hline $\mathrm{Cd}$ & $0.528 \pm 0.004$ & 2.9 & 94.3 & $4.6 \pm 0.2$ & 4.3 & 100 \\
\hline $\mathrm{Pb}$ & $1.49 \pm 0.01$ & 4.3 & 100.0 & $8.9 \pm 0.3$ & 3.1 & 101 \\
\hline $\mathrm{Cu}$ & $6.7 \pm 0.1$ & 1.5 & 100.0 & $8.7 \pm 0.2$ & 1.8 & 101 \\
\hline
\end{tabular}

* Recoveries for standard solutions are calculated by dividing the observed value by the expected value. The result is multiplied by 100 to give a percent recovery

Green turtles are herbivorous and feed on macroalgae, occupying a trophic level lower than carnivorous turtles. In this specie, $\mathrm{Cu}$ plays a crucial role in oxygen transport, energy production and enzyme activity, and it can be freely transferred from the mother to the egg [10]; however, although $\mathrm{Cd}$ and $\mathrm{Pb}$ do not perform any known role in biological systems, limited amounts were transferred, which suggests the relation of metal concentrations in egg. Trace metal concentrations in turtle eggs reported in this study were the largest compared to those measured by other authors in sea turtles $[10,12,15]$. We hypothesise that the concentrations of $\mathrm{Cd}, \mathrm{Pb}$ and 
$\mathrm{Cu}$ in turtle eggs could depend mainly on their feeding habits, as already suggested by other authors $[10,40]$. In addition to diet composition, age and gender could be important factors affecting metal excretion in egg.

\section{Conclusions}

Digestion techniques studied for the treatment of samples suggest that the EPA3050B technique should be used for the simultaneous analysis of $\mathrm{Cd}, \mathrm{Pb}$ and $\mathrm{Cu}$ in in brown algae and sea turtle eggs by anodic stripping voltammetry with square wave, as it showed the highest percentage recovery values with low coefficients of variation. The concentrations in brown algae (Sargasum natan) confirm that pollution in Antonio beach Guanahacabibes Protected Sea Park area is low, while the concentration in green turtle (Chelonia mydas) eggs suggest that it depends on their feeding habitats within the Caribbean Sea.

\section{References}

[1] P. S. Rainbow, Australas. J. Ecotoxicol. 12 (2006) 107-122.

[2] P. S. Rainbow, G. Blackmore, Mar. Environ. Res. 51 (2001) 441-463.

[3] P. S. Rainbow, B. D. Fialkowski, A. D. Smith, Wat. Res. 34 (2000) 1823-1829.

[4] P. S. Rainbow, Mar. Pollut. Bull. 31 (1995) 183-192.

[5] L. St-Cyr, P. Campbell, Can. J. Fish. Aquat. Sci. 57 (2000) 1330-1341.

[6] L. C. St-Cyr, P. G. C. Campbell, Can. J. Bot. 72 (1994) 429-439.

[7] M. M. Díaz, Zool. Inf. 31 (1995) 17-35.

[8] M. G. Lewander, M. Kautsky, L. Szareñ, Appl. Geochem. 11 (1996) 169-173.

[9] L. G. B. Calva, B. L. Fernández, G. V. Ponce, I. H. U. Salgado, A. V. Botello, Rev. Biol. Trop. 56 (2008) 1381-1390.

[10] H. Sakai, H. I. Suganuma, R. Tatsukawua, Mar. Pollut. Bull. 30 (1995) 347-353.

[11] H. Sakai, H. Suganuma, R. Tatsukawua, Mar. Pollut. Bull. 40 (2000) 701-709.

[12] D. L. Stoneburner, M. N. Nicora, E. R. Blood, J. Herpetol. 14 (1980) 171-176.

[13] S. Franzelliti, G. Gerosa, C. Vallini, E. Fabbri, Comp. Biochem. Physiol C 138 (2004) 187-194.

[14] Tesis Institucionales, http://tesis.ipn.mx/bitstream/handle/123456789/8954/DETMET.pdf (09/05/2014)

[15] L. Jame, S. Tanabe, E.K.W. Yuen, Mar. Pollut. Bull. 48 (2004) 164-192.

[16] En EPA 3050B: Compilation of EPA's Sampling and Analysis Methods (1996)

[17] En EPA 3050: Compilation of EPA's Sampling and Analysis Methods (1996)

[18] En EPA 3010A: Compilation of EPA's Sampling and Analysis Methods (1996)

[19] En APAHA-AWWA-WPCF: Standard Methods for the Examination of Water and Wastewater (2012)

[20] R. D. Riso, C. J. Chaumery, Anal. Chim. Acta 351 (1997) 83-89.

[21] E. Fischer, C.M.G. van der Berg, Anal. Chim. Acta 385 (1999) 273-280.

[22] C. G. T. Locatelli, Microchem. J. 65 (2000) 293-303.

[23] K. A. Rubinson, J. F. Rubinson, L. L. Ros, Análisis Instrumental, Pearson Education S.A, Madrid, España, 2004, p. 314

[24] J. Wang, Stripping analysis: principles, instrumentation, and applications, Wiley-VCH, Florida, United States of America, 1985, p. 250

[25] J. Wang, Analytical electrochemistry, Wiley-VCH, New York, United States of America, 2006, p. 223

[26] I. Palchetti, S. Laschi, M. Mascini, Anal. Chim. Acta 530 (2005) 61-67. 
[27] I. Palchetti, M. Mascini, M. Minunni, A. R. Bilia, F. F. Vincieri, J. Pharm. Biomed Anal. 32 (2003) 251-256.

[28] K. C. Honeychurch, J. P. Hart, Trends Anal. Chem. 22 (2003) 456-469.

[29] I. Palchetti, M. Mascini, A. P. F. Turner, Microchim. Acta 131 (1999) 65-73.

[30] F. Mocada, J. Azansa, G. Nodarse, Protocolo para el monitoreo de la anidación de Tortugas Marinas en Cuba. Centro de Investigaciones Marinas, La Habana. Cuba, 2010, p 50

[31] A. E. Tryfonas, J. K. Tucker, P. E. Brunkow, K. A. Jhonson, S. H. Hussein, Z-Q. Lin, Chemosphere 63 (2006) 39-48.

[32] V. Meucci, S. Laschi, M. Minunni, C. Pretti, L. Intorre, G. Soldani, M. Mascini, Talanta 77 (2009) 1143-1148.

[33] J. C. Miller, J. N. Miller, Estadística y Quimiometría para Química Analítica. Pearson Education S.A, Madrid, España, 1994, p 296

[34] I. Parchetti, M. Mascini, Microchem. Acta 131 (1999) 65-73.

[35] C. Locatelli, G. Torsi, Microchem. J. 65 (2000) 293-303.

[36] T. A. David, B. Volesky, H. S. Vieira, Wat. Res. 34 (2000) 4270-4278.

[37] A. M. Abdallah, A. Beltagy, E. Siam, Tox. Env. Chem. 88 (2006) 9-22.

[38] Direccional Nacional del Antártico. Instituto Antártico Argentino http://www.dna.gov.ar/CIENCIA/SANTAR04/CD/PDF/203BG.PDF (09/05/2014)

[39] E. Marcelo, G. C. Conti, Env. Res. 93 (2003) 99-112.

[40] J. S. Gray, Mar. Pollut. Bull. 45 (2002) 46-52.

C 2014 by the authors; licensee IAPC, Zagreb, Croatia. This article is an open-access article distributed under the terms and conditions of the Creative Commons Attribution license (http://creativecommons.org/licenses/by/4.0/) (cc) Br 